\title{
ANALISIS INVESTASI SEKTOR PARIWISATA OLEH PEMERINTAH DAERAH KOTA BATAM TAHUN 2014
}

\author{
NURHAYATI \\ Dosen Tetap Program Studi Ilmu Pemerintahan Universitas Kepulauan Riau (UNRIKA)
}

\begin{abstract}
Invesatasi sering disebut penanaman modal, merupakan pengeluaran perusahaan secara keseluruhan untuk membeli barang-barang modal riel, baik untuk mendirikan perusahaan baru maupun untuk memperluas usaha yang telah ada, dengan tujuan untuk memperoleh keuntungan khususnya pada sector pariwisata. Antusiasme pemerintah daerah belum sepenuhnya di barengi dengan agenda-agenda yang jelas dan komprehensif yang secara internal kreasikan sendiri oleh pemerintah daerah. Perumusan kebijakan investasi, penyempurnaan peraturan dan regulasi, penyusunan master-plan investasi, pengembangan sistem informasi investasi, pelayanan one-roof system atau one-stop shop, pengembangan partnership, belum kembangkan secara optimal oleh pemerintah daerah. investasi Sektor Pariwisata dimana investasi yang lakukan bidang pariwisata untuk mendukung pengembangan pariwisata terutama dalam memfasilitasi sarana parasana pariwisata dan juga destinasi pariwisata. Invetasi bidang pariwisata Indonesia sangat menjajikan hal ini di karenakan Negara Indonesia merupakan salah satu tujuan wisata yang minati oleh tourism mancanegara khususnya sector pariwisata Kota Batam.

Penelitian ini bertujuan untuk; meningkatkan investasi sektor pariwisata pemerintah Kota Batam, Penelitian investasi sektor pariwisata ini menggunakan pendekatan kualitatif. Dalam analisis data, diawali dengan menghimpun data melalui metode kepustakaan (dokumentasi), observasi dan wawancara.

Hasil Penelitian ini menyimpulkan; dalam mengelola sector pariwisata untuk menarik investasi pariwisata khususnya di Kota Batam dengan memberikan fasilitas baik sarana dan prasarana guna untuk menunjang prosedur pelayanannya kepada para investor dalam menanamkan modal usaha disektor pariwisata. Pemerintah Daerah Kota Batam sudah merealisasikan beberapa kegiatan kepariwisataan guna investasi dalam mengembangkan obyek pariwisata yaitu meningkatkan pengembangan obyek wisata yang dimiliki Kota Batam. Selain itu juga guna untuk investasi penguatan modal pelaku pariwisata Kota Batam.

Penelitian ini merekomendasikan; Diharapkan Pemerintah Kota Batam mendorong pertumbuhan investasi sektor pariwisata, serta semakin meningkatkan pergerakkan investasi sektor pariwisata serta Pemerintah Kota Batam diharapkan lebih fokus memperhatikan perkembangan pembangunan sektor pariwisata yang dapat menyerap tenaga kerja lebih banyak lagi pada sektor pariwisata.
\end{abstract}

Kata kunci: Investasi Dan Pariwisata.

\section{LATAR BELAKANG}


Pertengahan tahun 1997 pariwisata Indonesia mencapai puncak kejayaannya karena telah memberikan kontribusi cukup besar terhadap perolehan devisa bagi negara disamping Pendapatan Asli Daerah (PAD). Tetapi pada tahun 1997 juga merupakan titik balik dari kejayaan pariwisata Indonesia, karena di tahun 1997 pula terjadi krisis demi krisis sehingga pariwisata menjadi terpuruk hingga penutup tahun 2000. (Yoeti A, Oka: 2005)

Pariwisata Indonesia saat ini sedang mengalami masa yang cukup rumit, hal ini karena berbagai persoalan, khususnya sektor pariwisata yang menjadi salah satu ujung tombak dan icon bangsa Indonesia. Sering terjadinya konflik dan terorisme yang semakin meluas yang menyebabkan semakin menurunya jumlah wisatawan yang berkunjung ke Indonesia. Menurunya jumlah wisatawan ini membawa dampak buruk bagi semua sektor, seperti: sepinya hunian perhotelan yang ada daerah-daerah, bisnis bidang pariwisata semakin menurun, Pendapatan Asli Daerah (PAD) semakin menurun.

Peran pemerintah daerah dalam mengembangkan sektor pariwisata sangatlah diperlukan, mengingat pariwisata dalam pembangunan daerah pada garis besarnya menitikberatkan pada segi ekonomis (sumber devisa pajak), segi sosial (penciptaan lapangan pekerjaan). Untuk memperlancar dan mempercepat hasil pembangunan pariwisata maka Dinas Pariwisata dan Kebudayaan Kota batam selaku pengerak utama dalam mengembangkan pariwisata perlu melakukan strategi dalam pengembangan pariwisata daerah mengingat persaingan dunia wisata yang cukup kompetitif. Sebagaimana sebuah bentuk pengembangan ekonomi maka pengembangan industri pariwisata pun sebagai bagian dari sebuah gejala ekonomi bisnis memerlukan rencana yang baik bila ingin sukses dalam obyek yang implisit maupun eksplisit.

Dinas Pariwisata dan Kebudayaan Kota batam memiliki peranan penting dalam menarik para investment dalam sector pariwisata khususnya. Sector pariwisata di wujudkan melalui Visi dan Misi dari sector pariwisata tersebut, hal ini Dinas pariwisata dan kebudayaan kota Batam diperkuat dengan beberapa Misi diantaranya:

1. Melestarikan Nilai serta Mengembangkan Keragaman dan Kekayaan budaya Bangsa dengan tetap menjadikan Budaya Melayu sebagai Payung Negeri;

2. Meningkatkan kualitas Sumber Daya Manusia serta Pengelolaan Sarana dan Prasarana Kepariwisataan;

3. Mengembangkan Industri Pariwisata yang berdaya saing, Destinasi yang unggul serta Pemasaran dan Promosi Pariwisata yang berkelanjutan

Senada dengan Visi dan Misi sector pariwisata Kota Batam dilihat dari beberapa data obyek wisata yang dimiliki oleh Dinas Pariwisata dan Kebudayaan Kota Batam, seperti uraian tabel dibawah:

Tabel

Data nama obyek wisata Kota Batam, 2014

\begin{tabular}{|c|l|l|}
\hline No & Obyek Wisata Kota Batam \\
\hline \multicolumn{2}{|c|}{ Wisata Budaya } \\
\hline 1 & Tari Zapin \\
\hline
\end{tabular}




\begin{tabular}{|c|c|}
\hline 2 & Rebana \\
\hline 3 & Kompang \\
\hline 4 & Gasing \\
\hline 5 & Mak Yong (pertunjukan melayu) \\
\hline \multicolumn{2}{|c|}{ Wisata Bahari/Laut } \\
\hline 1 & Pulau Abang \\
\hline 2 & Pulau Melur \\
\hline 3 & Pantai Nongsa \\
\hline 4 & Pulau Putri \\
\hline 5 & Jembatan Barelang \\
\hline 6 & Pulau Belakang Padang \\
\hline \multicolumn{2}{|c|}{ Wisata Belanja } \\
\hline 1 & BCS Mall \\
\hline 2 & Nagoya Hill Superblock \\
\hline 3 & Mega Mall \\
\hline 4 & Kepri Mall \\
\hline 5 & Kek Pisang Villa \\
\hline 6 & Cake Buah Naga Aroma \\
\hline 7 & Bingka Bakar \& Kue Bilis Nay@dam \\
\hline \multicolumn{2}{|c|}{ Wisata Olah Raga } \\
\hline 1 & Golf \\
\hline 2 & Canoeing \\
\hline 3 & Jet Sky \\
\hline 4 & Banana Boat \\
\hline 5 & Parasailing \\
\hline \multicolumn{2}{|c|}{ Wisata Religi } \\
\hline 1 & Masjid Agung Batam \\
\hline 2 & Patung Dewi Kwan IM \\
\hline 3 & Pura Agung Amertha Buana \\
\hline 4 & Vihara Duta Materya \\
\hline 5 & GPIB Emmanuel Batam \\
\hline \multicolumn{2}{|c|}{ Wisata Sejarah } \\
\hline 1 & Kampung Vietnam (Memorial of Galang), Kecamatan Rempang Cate \\
\hline 2 & Rumah Limas Potong, Batu Besar Kecamatan Nongsa \\
\hline 3 & $\begin{array}{l}\text { Komplek Makam Keluarga Nong Isa (Raja Isa), Nongsa Pantai } \\
\text { Kecamatan Nongsa }\end{array}$ \\
\hline 4 & Perigi Air Raja, Air Raja Kecamatan Galang \\
\hline 5 & $\begin{array}{l}\text { Cerobong Asap Pabrik Batu Bata Brick Work Raja Ali Kelana, } \\
\text { Kecamatan Batu Aji }\end{array}$ \\
\hline 6 & $\begin{array}{l}\text { Komplek Makam Keluarga Temenggung Abdul Jamal, Kecamatan } \\
\text { Bulang }\end{array}$ \\
\hline 7 & Komplek Makam Putri Dahlia, Subang Mas Kecamatan Galang \\
\hline 8 & Pilar Tri Angulasi Gunung Kedap, Batu Besar Kecamatan Nongsa \\
\hline 9 & Komplek Makam Tua, Batu Besar Kecamatan Nongsa \\
\hline 10 & Masesebo, Sembulang Kecamatan Galang \\
\hline 11 & Makam Tua Syekh Abdul Rahman, Sei Lekop Kecamatan Sagulung \\
\hline 12 & Miniatur Budaya Nusantara, Bengkong Laut Kecamatan Bengkong \\
\hline \multicolumn{2}{|c|}{ Wisata Perkebunan (Ekowisata) } \\
\hline 1 & Hutan Bakau Nongsa \\
\hline 2 & Kebun Buah Naga \\
\hline 3 & Bunga Rosella \\
\hline
\end{tabular}




\begin{tabular}{|c|l|}
\hline 4 & Hutan Wisata Mata Kucing \\
\hline \multicolumn{2}{|l|}{} \\
Wisata MICE \\
\hline 1 & Planet Holiday Hotel \\
\hline 2 & Hotel Novotel \\
\hline 3 & Pacific Palace Hotel Dan Lain Lain
\end{tabular}

Sumber: Dinas Pariwisata dan Kebudayaan Kota batam, 2014

Pemerintah daerah dalam hal ini adalah Dinas Pariwisata dan Kebudayaan Kota Batam memiliki tantangan mendatangkan jumlah investor dan wisatawan ke Kota Batam, membuat Pemerintah Kota Batam harus meningkatkan investment dan kunjungan wisatawan yang dilakukan oleh Dinas Pariwisata dan Kebudayaan Kota Batam. Sebagai salah satu industri jasa, Pariwisata sangat berperan sebagai sumber penghasil devisa bagi Kota Batam. Sektor pariwisata ini mempunyai potensi baik untuk menciptakan kesempatan kerja dan kesempatan berusaha serta untuk meningkatkan dan memeratakan pendapatan masyarakat dan daerah.

Pariwisata memiliki potensi untuk berkembang lebih pesat dan memberikan sumbangan yang lebih besar kepada pembangunan daerah maupun nasional. Oleh karena itu, perlu di tingkatkan invesment yang lebih luas lagi dalam rangka investasi Pariwisata Kota Batam. Adapun tingkat kunjungan wisatawan mancanegara yang datang ke Kota Batam. Untuk memperkuat argumentasi diatas, adapun data kunjungan wisatawan mancanegara tahun 2013 pada uraian tabel dibawah:

Tabel

Data Kunjungan Wisatawan Mancanegara

SEMESTER I

\begin{tabular}{c|l|c|c|c|c|c|c|}
\hline \multirow{2}{*}{ No } & \multirow{2}{*}{$\begin{array}{c}\text { Nama } \\
\text { Negara }\end{array}$} & \multicolumn{7}{|c|}{ Bulan } \\
\cline { 3 - 8 } & & Jan & Feb & Mar & Apr & Mei & Juni \\
\hline 1 & 2 & 3 & 4 & 5 & 6 & 7 & 8 \\
\hline 1. & Singapura & 45.324 & 55.733 & 69.778 & 48.439 & 60.446 & 77.262 \\
\hline 2. & Malaysia & 12.569 & 15.252 & 13.489 & 14.206 & 14.633 & 17.122 \\
\hline 3. & $\begin{array}{l}\text { Korea } \\
\text { Selatan }\end{array}$ & 6.481 & 4.709 & 5.549 & 4.740 & 4.514 & 4.666 \\
\hline 4. & Philipina & 2.165 & 3.261 & 3.191 & 3.142 & 3.738 & 3.008 \\
\hline 5. & India & 2.265 & 4.158 & 3.368 & 3.045 & 3.268 & 3.219 \\
\hline 6. & Jepang & 1.693 & 1.882 & 2.157 & 1.628 & 2.033 & 1.811 \\
\hline 7. & China & 1.807 & 3.558 & 2.283 & 2.102 & 2.206 & 2.607 \\
\hline 8. & Inggris & 1.157 & 1.232 & 1.336 & 1.262 & 1.476 & 1.126 \\
\hline 9. & $\begin{array}{l}\text { Amerika } \\
\text { Serikat }\end{array}$ & 876 & 893 & 1.031 & 906 & 1.029 & 1.124 \\
\hline 10. & Australia & 951 & 930 & 1.100 & 938 & 1.025 & 975 \\
\hline
\end{tabular}




\begin{tabular}{|c|c|c|c|c|c|c|}
\hline 11. Taiwan & 215 & 359 & 320 & 300 & 342 & 334 \\
\hline 12. Jerman & 331 & 324 & 455 & 293 & 388 & 284 \\
\hline 13. Belanda & 272 & 291 & 347 & 267 & 300 & 314 \\
\hline 14. Perancis & 253 & 309 & 327 & 296 & 304 & 315 \\
\hline 15. Hongkong & 91 & 156 & 64 & 169 & 153 & 140 \\
\hline 16. Thailand & 284 & 414 & 471 & 374 & 355 & 280 \\
\hline 17. Rusia & 53 & 48 & 44 & 14 & 73 & 45 \\
\hline 18. Mesir & 8 & 10 & 16 & 15 & 9 & 7 \\
\hline 19. $\begin{array}{l}\text { Saudi } \\
\text { Arabia }\end{array}$ & 6 & 14 & 33 & 18 & 4 & 17 \\
\hline $\begin{array}{l}\text { 20. Uni Emirat } \\
\text { Arab }\end{array}$ & 8 & - & 1 & 3 & 5 & 13 \\
\hline 21. Bahrain & 1 & 7 & 1 & 4 & 1 & 16 \\
\hline 22. Lainnya & 12.440 & 11.840 & 14.810 & 11.002 & 13.033 & 11.592 \\
\hline Jumlah & 89.250 & 105.380 & 120.271 & 93.163 & 109.335 & 126277 \\
\hline
\end{tabular}

Sumber: Dinas Pariwisata dan Kebudayaan Kota batam, 2014

Tabel

Data Kunjungan Wisatawan Mancanegara

SEMESTER II

\begin{tabular}{|c|c|c|c|c|c|c|c|}
\hline \multirow{2}{*}{ No } & \multirow{2}{*}{$\begin{array}{l}\text { Nama } \\
\text { Negara }\end{array}$} & \multicolumn{6}{|c|}{ Bulan } \\
\hline & & Juli & August & Sept & Okt & Nov & Des \\
\hline 1 & 2 & 3 & 4 & 5 & 6 & 7 & 8 \\
\hline 1. & Singapura & 47332 & 59213 & 61804 & 57300 & 71943 & 99037 \\
\hline 2. & Malaysia & 13721 & 17329 & 15846 & 14337 & 18170 & 20414 \\
\hline 3. & Korea Selatan & 3367 & 3845 & 3651 & 4982 & 5854 & 4297 \\
\hline 4. & Philipina & 2488 & 3364 & 2998 & 3068 & 3434 & 3417 \\
\hline 5. & India & 2656 & 4002 & 2882 & 2735 & 2862 & 3669 \\
\hline 6. & Jepang & 2045 & 1933 & 1885 & 1884 & 2150 & 2029 \\
\hline 7. & China & 2877 & 3595 & 2548 & 2390 & 2743 & 3001 \\
\hline 8. & Inggris & 1174 & 1427 & 1330 & 1361 & 1359 & 1175 \\
\hline 9. & $\begin{array}{l}\text { Amerika } \\
\text { Serikat }\end{array}$ & 933 & 1083 & 1265 & 952 & 973 & 851 \\
\hline 10. & Australia & 941 & 990 & 1035 & 940 & 977 & 960 \\
\hline 11. & Taiwan & 409 & 424 & 389 & 359 & 372 & 396 \\
\hline 12. & Jerman & 381 & 414 & 333 & 393 & 340 & 286 \\
\hline 13. & Belanda & 385 & 388 & 394 & 410 & 371 & 348 \\
\hline
\end{tabular}




\begin{tabular}{c|l|c|c|c|c|c|c|}
\hline 14. & Perancis & 309 & 304 & 285 & 294 & 333 & 289 \\
\hline 15. & Hongkong & 209 & 202 & 133 & 172 & 216 & 186 \\
\hline 16. & Thailand & 562 & 624 & 674 & 770 & 315 & 387 \\
\hline 17. & Rusia & 43 & 59 & 23 & 57 & 52 & 58 \\
\hline 18. & Mesir & 12 & 9 & 8 & 5 & 13 & 10 \\
\hline 19. & Saudi Arabia & 11 & 18 & 7 & 8 & 7 & 14 \\
\hline 20. & $\begin{array}{l}\text { Uni Emirat } \\
\text { Arab }\end{array}$ & 7 & 2 & 2 & 6 & - & - \\
\hline 21. & Bahrain & - & 3 & - & 2 & - & - \\
\hline 22. & Lainnya & 11194 & 13112 & 10723 & 11086 & 11351 & 12973 \\
\hline Jumlah & 91056 & 112340 & 108215 & 103511 & 123835 & 153797 \\
\hline
\end{tabular}

Sumber: Dinas Pariwisata dan Kebudayaan Kota batam, 2014

Adapun data pembanding untuk memperkuat data tingkat kunjungan wisatawan mancanegara tahun 2014 seperti uraian tabel dibawah:

Tabel

Data Kunjungan Wisatawan Mancanegara Tahun 2014

\begin{tabular}{|c|c|c|c|c|c|c|c|}
\hline \multirow{2}{*}{ No } & \multirow{2}{*}{ Nama Negara } & \multicolumn{6}{|c|}{ Bulan } \\
\hline & & Januari & Februari & Maret & April & Mei & Juni \\
\hline 1 & 2 & 3 & 4 & 5 & 6 & 7 & 8 \\
\hline 1 & Singapura & 68.323 & 51.542 & 72.622 & 63.162 & 64.651 & 90.349 \\
\hline 2 & Malaysia & 13.378 & 13.209 & 14.461 & 13.647 & 15.979 & 17.670 \\
\hline 3 & Korea Selatan & 6.967 & 6.918 & 6.202 & 5.218 & 3.840 & 3.503 \\
\hline 4 & Philipina & 3.204 & 2.792 & 3.086 & 3.355 & 3.919 & 3.241 \\
\hline 5 & India & 3.773 & 3.029 & 3.105 & 3.202 & 3.787 & 3.424 \\
\hline 6 & Jepang & 1.881 & 1.809 & 1.958 & 1.800 & 2.025 & 1.887 \\
\hline 7 & China & 3.191 & 2.743 & 2.626 & 2.612 & 2.534 & 2.714 \\
\hline 8 & Inggris & 1.250 & 1.247 & 1.424 & 1.401 & 1.565 & 1.193 \\
\hline 9 & $\begin{array}{l}\text { Amerika } \\
\text { Serikat }\end{array}$ & 1.047 & 1.025 & 1.165 & 1.042 & 1.064 & 1.064 \\
\hline 10 & Australia & 1.073 & 867 & 1.049 & 1.058 & 1.074 & 1.031 \\
\hline 11 & Taiwan & 385 & 512 & 435 & 416 & 288 & 376 \\
\hline 12 & Jerman & 320 & 350 & 379 & 386 & 392 & 297 \\
\hline 13 & Belanda & 385 & 340 & 389 & 372 & 376 & 300 \\
\hline 14 & Perancis & 351 & 301 & 360 & 425 & 391 & 342 \\
\hline 15 & Hongkong & 203 & 214 & 246 & 210 & 181 & 187 \\
\hline 16 & Thailand & 282 & 263 & 263 & 301 & 342 & 39 \\
\hline 17 & Rusia & 84 & 49 & 70 & 45 & 46 & 38 \\
\hline 18 & Mesir & 19 & 12 & 4 & 9 & 11 & 18 \\
\hline 19 & Saudi Arabia & 15 & 33 & 12 & 29 & 81 & 20 \\
\hline
\end{tabular}




\begin{tabular}{c|l|c|c|c|c|c|c|}
\hline 20 & $\begin{array}{l}\text { Uni Emirat } \\
\text { Arab }\end{array}$ & 2 & - & 2 & - & 7 & 7 \\
\hline 21 & Bahrain & 1 & - & 1 & 1 & - & - \\
\hline 22 & Lainnya & 12.920 & 10.190 & 12.160 & 13.238 & 12.770 & 12.228 \\
\hline \multicolumn{1}{c|}{ Jumlah } & 119.054 & 97.445 & 122.019 & 111.929 & 115.323 & 140.218 \\
\hline $\begin{array}{c}\text { Total wisman } \\
\text { Januari-Juni 2014 }\end{array}$ & \multicolumn{7}{|c|}{$\mathbf{7 0 5 . 9 8 8}$} \\
\hline
\end{tabular}

Sumber: Dinas Pariwisata dan Kebudayaan Kota batam, 2014

Sektor pariwisata merupakan sarana yang efektif untuk lebih mengenal, mempelajari dan mengetahui suatu negara, masyarakat, dan budayanya dimana peminat wisata baik mancanegara maupun lokal yang berkunjung pada suatu daerah tujuan wisata memiliki motivasi untuk menyaksikan dan melihat keindahan alam termasuk dalamnya Wisata Budaya, Wisata Bahari/Laut, Wisata Belanja, Wisata Olah Raga, Wisata Religi, Wisata Sejarah, Wisata Perkebunan (Ekowisata) dan Wisata MICE khususnya yang ditawarkan Kota Batam.

\section{Rumusan Masalah \& Tujuan Penelitian}

Berdasarkan permasalahan yang muncul dari latar belakang masalah yang penulis paparkan diatas, maka penulis merumuskan masalah sebagai berikut: Bagaimana pemerintah daerah Kota Batam mengelola sektor pariwisata untuk menarik investasi dan tujuan penelitian ini untuk mendeskripsikan kebijakan sektor pariwisata untuk menarik investasi serta sebagai bahan pertimbangan bagi Pemerintah dalam menentukan arah kebijakan selanjutnya terutama kaitannya dengan investasi pemerintah daerah dalam rangka meningkatkan kunjungan wisatawan dan invesment baik dalam maupun luar negeri pada sektor pariwisata.

\section{Landasan Teori \\ Investasi Sektor Pariwisata}

\section{Investasi}

Menurut Deliamor (1985:82), investasi atau sering disebut penanaman modal, merupakan pengeluaran perusahaan secara keseluruhan untuk membeli barang-barang modal riel, baik untuk mendirikan perusahaan baru maupun untuk memperluas usaha yang telah ada, dengan tujuan untuk memperoleh keuntungan. Sedangkan Menurut Rudiger Dorenbush, Stonley Ficher (1989-268), investasi adalah pengeluaran yang ditunjukan untuk meningkatkan atau mempertahankan stok barang modal dalam suatu produksi untuk meningkatkan output produksi.

Menurut Rose (2005:5), investasi adalah suatu pengeluaran pada barang modal atau pada perseiaan barang mentah yang digunakan untuk memperoduksi barang atau jasa lain yang mengakibatkan produksi dan pendapatan dimasa yang akan datang. Dan masalah investasi baik penentuan jumlah maupun kesempatan untuk melakukan investasi, oleh Keynes didasarkan atas konsep marginal productivity of investment (MEI) yaitu bahwa investasi itu akan dijalankan oleh seseorang pengusaha bila MEI lebih tinggi daripada tingkat bunga (interest rate). Jelasnya investasi ditentukan oleh faktor-faktor diluar interest rate (Teori J.M Keynes).

Penanaman Modal Asing (PMA) Menurut pasal 1 Undang-undang PMA No.1 Tahun 1967 dalam Manajemen Penanaman Modal Asing dinyatakan sebagai berikut: Pengertian penanaman 
modal asing hanya meliputi modal asing secara langsung yang digunakan untuk menjalankan perusahaan Indonesia dalam arti menanggung resiko secara langsung bagi pemilik modal tersebut dalam menanamkan modalnya. Bagian dari kekayaan masyarakat Indonesia, termasuk hak dan benda-benda, baik yang dimiliki oleh negara maupun Indonesia PMA disesuaikan dengan prioritas pembangunan yang sedang dijalankan. Jadi faktor-faktor tertentu yang tertutup bagi PMA dengan pertimbangan sektor tersebut diperuntukkan bagi pengusaha penanaman modal tersebut diusahakan dapat memberikan manfaat yang besar bagi kepentingan Indonesia dan modal tersebut diarahkan oleh pemerintah dengan memperhatikan perkembangan ekonomi nasional.

Investasi Daerah merupakan besarnya peluang pemerintah daerah dalam rangka mengembangkan daerah melalui berbagai macam aktifitas dan program pemerintah daerah memberikan keleluasaan kepada daerah untuk untuk mengatur beberapa kewenangan pemerintah dalam rangka mensejahterakan masyarakat yang ada daerah, hal ini sesuai dengan UU 32 tahun 2004 yang memberikan kewenangan kepada pemerintah daerah untuk mengatur rumah tangga mereka sediri. Semakin banyaknya investor yang masuk ke daerah-daerah untuk berinvestasi membuka peluang yang besar kepada daerah untuk memajukan daerah.

Investasi daerah adalah salah satu strategi dalam rangka menumbuh kembangkan potensi-potensi yang miliki oleh daerah, melalui investasi daerah ini harapkan nantinya kondisi daerah akan menjalebih baik lagi. Sesuai dengan Permen no 52 tahun 2012 pasal 1 butir ke 3 Investasi Pemerintah Daerah adalah penempatan sejumlah dana atau barang milik daerah oleh pemerintah daerah dalam jangka panjang untuk investasi pembelian surat berharga dan investasi langsung, yang mampu mengembalikan nilai pokok tambah dengan manfaat ekonomi, sosial, dan manfaat lainnya dalam jangka waktu tertentu.

Selain itu investasi daerah merupakan salah satu kekuatan penting untuk mengakselerasi pembangunan daerah. Namun untuk merancang investasi butuhkan agenda-agenda yang jelas dan komprehenshif secara internal kreasikan sendiri oleh pemerintah daerah. Secara normatif, investasi daerah (local investment) dipahami sebagai salah satu kekuatan penting untuk mengakselerasi pembangunan daerah. Tak terkecuali kalangan pemerintah daerah, timbul semacam kesadaran terlebih sesudah implementasi desentralisasi dan otonomi daerah bahwa akselerasi pembangunan hanya mungkinkan jika terdapat arus investasi yang signifikan. Persepsi yang kuat tentang pentingnya investasi telah mendorong pemerintah daerah untuk melakukan berbagai upaya, mulai dari promosi investasi yang gencar hingga kunjungan pejabat daerah keluar negeri.

Namun secara umum, antusiasme pemerintah daerah tersebut belum sepenuhnya barengi dengan agenda-agenda yang jelas dan komprehensif yang secara internal kreasikan sendiri oleh pemerintah daerah. Perumusan kebijakan investasi, penyempurnaan peraturan dan regulasi, penyusunan master-plan investasi, pengembangan sistem informasi investasi, pelayanan one-roof system atau one-stop shop, pengembangan partnership, belum kembangkan secara optimal oleh pemerintah daerah. (http://bappedarejanglebong.net/).

Menurut Kuntjoro (2011:10) investasi merupakan suatu bentuk penudaan konsumsi dari masa sekarang untuk masa yang akan datang, yang dalamnya terkandung resiko tidak pastian, untuk itu butuhkan suatu kompensasi atas penundaan tersebut yang bisa kenal dengan istilah keuntungan dari investasi atau gain. Sedangkan Investasi menurut Eduardus Tandelilin (2010:2) merupakan komitmen atas sejumlah dana atau sumber daya lainnya yang lakukan pada saat ini, dengan tujuan untuk memperoleh sejumlah keuntungan masa datang.

Kata investasi merupakan kata adopsi dari bahasa inggris yaitu investment. Kata invest sebagai kata dasar memiliki arti menanam. Dalam webster new collegiate dictionary, kata invest didefinisikan sebagai "to make use of for future benefit or advantage and to commit (money) in order to earn financial return. Dalam kamus lengkap ekonomi, investasi definisikan sebagai 
penukaran uang dengan bentuk-bentuk kekayaan yang lain seperti saham atau harta tidak bergerak yang diharapkan dapat tahan selama periode waktu tertentu supaya menghasilkan pendapatan.

Menurut Doli D. Siregar dalam bukunya Manajemen Aset (hal 479-480). Menyatakan dalam memilih kebijakan investasi atas suatu dana adalah hal terpenting dan akan menjadi masalah membinggungkan yang hadapi oleh para penyandang dana dan para fund managers. Hanya sedikit suatu keputusan yang menyakinkan, berdasarkan analisis rasional, sebagaimana seharusnya suatu kebijakan. Sebagai konsekuensinya masalah ini akan dibahas secara panjang lebar, namun masih dalam perspektif berikut: pertama, tujuan dari dana adalah untuk mendukung tujuan-tujuan organisasi penyandang dana, dan kedua, kebijakan investasi atau resiko dari dana seharusnya maksimalkan untuk mencapai tujuan dalam mendukung tujuan organisai.

Menurut Kamus Besar Bahasa Indonesia, Investasi artikan sebagai penanaman uang atau suatu perusahaan atau proyek untuk tujuan memproleh keuntungan. Pada dasarnya investasi adalah membeli suatu aset yang harapkan masa datang dapat jual kembali dengan nilai yang lebih tinggi. Investasi juga dapat katakan sebagai suatu penundaan konsumsi saat ini untuk konsumsi masa depan. Harapan pada keuntungan masa datang merupakan kompensasi atas waktu dan risiko yang terkait dengan suatu investasi yang lakukan. Secara umum bentuk aset yang investasikan terbagi menjadi dua jenis yaitu Riil Investment yaitu menginvestasikan sejumlah dan tertentu pada aset berwujud, seperti halnya tanah, emas, bangunan, dan lain-lain dan Financial Investment yaitu menginvestasikan sejumlah dana tertentu pada aset finansial, seperti halnya deposito, saham, obligasi, dan lain-lain. Dalam hal ini surat berharga yang perdagangkan atau yang sering disebut dengan efek adalah berupa saham.

\section{Pariwisata}

Menurut Oka A. Yoeti (1985:103 ) Pariwisata secara etimologis berasal dari bahasa sangsakerta yang terdiri dari dua suku kata yaitu "pari" yang berati banyak, berkali-kali, berputar-putar dan lengkap. Sedangkan "wisata" yang berarti perjalanan atau berpergian. Dengan demikian pengertian kata pariwisata dapat simpulkan sebagai suatu perjalanan yang lakukan secara berkali-kali atau berputar-putar dari suatu tempat ke tempat yang lain.

Hakikatnya berpariwisata adalah suatu proses berpergian sementara dari sesorang atau lebih menuju tempat lain luar tempat tinggalnya. Dorongan berpergian adalah karena berbagai kepentingan baik karena kepentingan ekonomi, sosial, kebudayaan, politik, agama, kesehatan maupun kepentingan lain seperti sekedar ingin tahu, menambah pengalaman ataupun untuk belajar. Senada menurut Yoeti (1996:118) mengemukakan pengertian pariwisata sebagai kegiatan rekreasi yang selenggarakan dari suatu tempat ketempat lain dengan maksud bukan untuk berusaha atau mencari nafkah di tempat yang kunjungi, tetapi semata-mata untuk menikmati perjalanan tersebut guna bertamasya dan rekreasi atau untuk memenuhi keinginan yang beranekaragam.

Menurut Pendit (1990:30) Pariwisata adalah berpergiannya orang-orang tersebut dapat lukiskan dengan banyak orang yang meninggalkan tempat kediaman atau rumah mereka untuk sementara waktu ketempat lain dengan tujuan bener-bener sebagai konsumen dan sama sekali tanpa tujuan mencari nafkah.

Pariwisata merupakan salah satu segi mobilitas manusia. Namun perbedaan pengertian mobilitas manusia dan pariwisata hanyalah perbedaan semu bukan hakiki, lebih-lebih tinjau dari segi kesamaan sarana dan prasarana yang perlukan. Dengan demikian berbagai motivasi mobilitas manusia dapat merupakan pula motivasi kepariwisataan, apakah sebagai motivasi utama atau sampingan. Menurut Direktur Jendderal Pariwisata (1976:25). 
Pengertian industri pariwisata menurut Kusudianto (1996:11) yaitu suatu susunan organisasi, baik pemerintah maupun swasta yang terkait dalam pengembangan, produksi dan pemasaran produk suatu layanan yang memenuhi kebutuhan dari orang yang sedang berpergian. Senada hal atas menurut Direktur Jendderal Pariwisata (1976:40) Industri wisata ialah perusahaan penginapan, angkutan wisata, perusahaan biro perjalanan, perusahaan perstauranan dan perusahaan hiburan.

Methieson dan Wall (1982:46) mengatakan bahwa pariwisata mencangkup tiga elemen utama adalah:

1. Adynamic elemen yaitu: trevel kesatuan destinasi wisata.

2. Astratic elemen yaitu: singgah daerah tujuan

3. Aconsequentional elemen yaitu: akibat dari hal atas khususnya terhadap masyarakat lokal yang meliputi dampak ekonomi sosial pisik dan adanya kontak dan wisatawan.

Senada dengan hal itu Tingkat pengaruh wisatawan dalam proses produksi wisata dapat diidentifikasikan melalui dua hal yaitu profil wisatawan dan motivasi wisatawan. Menurut Suyitno (1999:16) "profil wisatawan yaitu hal-hal yang merupakan ciri-ciri khusus wisatawan yang membedakan antara yang satu dengan yang lainnya". Karaktristik ini muncul karena dua latar belakang, yaitu:

1. Latar belakang lingkungan berupa kondisi alam, latar belakang sejarah, kebudayaan, politik, ekonomi, serta faktor sosial.

2. Latar belakang pribaantara lain tingkat umur wisatawan, jenis kelamin, pendidikan serta profesi atau mata pencahariaan.

Motivasi adalah dorongan psikologis yang mengarahkan seseorang kearah satu tujuan

alasan orang untuk mengunjungi objek wisata biasanya berbeda-beda tergantung motivasinya, adapun motivasi berwisata menurut Yoeti (1996:82) terdiri dari:

1. Motivasi fisik (physical motivation), tujuan mengembalikan kondisi fisik, caranya dengan beristirahat, bersantai atau olahraga sehingga timbul kembali semangat untuk beraktivitas.

2. Motivasi budaya (culture motivations), tujuannya berkaitan erat dengan keinginan pribauntuk melihat dan mengetahui negara lain baik penduduknya maupun tata cara hidup yang berbeda.

3. Motivasi interpersonal (interpersonal motivations), yaitu berkaitan dengan keinginan untuk bertemu dengan naak keluarga, teman, tetangga, berjumpa dengan orang-orang tertentu atau sekedar melihat tokoh-tokah terkenal, benyayi, bintang filem, dan lainlain.

Berdasarkan jenisnya maka objek wisata terbagi menjatiga jenis, antaranya adalah:

1. Objek dan daya tarik wisata alam, yang berupa objek wisata alamiah seperti sungai, danau, gunung, hutan dan sebagainya, dan ada juga yang berupa objek wisata alam yang mendapat campur tangan manusia seperti sawah, danau buatan, saluran irigasi, dan sebagainya.

2. Objek dan daya tarik wisata budaya yaitu seluruh ungsur karya cipta dan karsa manusia yang implementasikan dalam gaya hidup upacara adat atau ungsur tradisional lainnya.

3. Objek dan daya tarik wisata buatan yaitu objek wisata yang bangun untuk berwisata seperti taman bermain dan area pemainan.

Direktur Jenderal Pariwisata (1976:29-39) Berdasarkan manfaat pariwisata terbagi menjadi beberapa bagian yang meliputi yaitu:

1. Ekonomi 
Belanja para wisatawan asing suatu negara tujuan merupakan penerimaan valuta asing atau devisa. Semakin besar belanja tersebut, akan makin memperkuat neraca pembayaran negara tujuan. Dari segi lain Negara dapat menambah pendapatan dari penerimaan pajak-pajak dari sektor-sektor usaha yang bersangkutan dengan kepariwisataan.

\section{Seni Budaya}

Salah satu dorongan kebutuhan manusia untuk mengunjungi sesuatu daerah ialah untuk memenuhi rasa ingin mengetahui, mengagumi atau menyelami seni budaya dari daerah yang kunjunginya. Dengan demikian pada dasarnya wisatawan ingin melihat sesuatu yang jarang, keperibadian (asli) tetapi indah. Kebutuhan ini akan mendorong pengembangan kreasi, penggalian, pemeliharaan, atau pagelaran seni budaya yang baik.

3. Pemeliharaan dan manfaat lingkungan hidup

Pembangunan pariwisata yang tidak teratur dan terarah dapat merusak lingkungan hidup, sebaliknya apabila bina secara baik justru menjapendorong pemeliharaan lingkungan yang baik ataupun dapat memanfaatkan lingkungan alam yang terlantar. Wisatawan yang mempunyai tujuan untuk rekreasi menginginkan suatu daerah yang menimbulkan suasana baru dari kebisingan kehidupan sehari-hari.

4. Memperluas nilai-nilai pergaulan hidup dan pengetahuan

Hubungan-hubungan yang terjalin antara wisatawan dengan masyarakat yang kunjunginya sedikit banyak akan menempa nilai hidup baru dalam arti memperluas cakrawala (horizon) pandangan pribaterhadap nilai-nilai kehidupan lainnya. Manusia akan belajar menghargai nilai-nilai orang lain disamping nilai-nilai yang milikinya dalam hubungan dengan kegiatan wisatawan dalam negri maka lebih mengenal tanah air.

5. Memperluas kesempatan kerja

Perusahaan dalam lingkup industri pariwisata yang menyerap banyak tenaga.

Berdasarkan penelitian UNDP/ILO (Manpower survey on tourist development dan tourist industry in indonesia 1974) jumlah tenaga kerja sektor pariwisata berjumlah 48.300. apabila rangkaian tenaga kerja pada industri penunjang pariwisata seperti, 
perusahaan kerajinan, dekorasi hotel, toko souvenir dan sebagainya, maka jumlah tenaga kerja yang diserap makin banyak lagi.

6. Menunjang perbaikan kesehatan dan prestasi kerja

Manusia selalu menginginkan terlepas dari kejemuan kesibukan hidup sehari-

hari atau rasa bosan dengan mendambakan suasana baru, lingkungan baru walaupun untuk sementara. Kejemuan yang berlarut-larut menimbulkan tekanan jiwa yang akan mempengaruhi kesehatan maupun prestasi kerja. Dengan adanya rekreasi ke suatu lingkungan suasana baru akan mengendorkan ketenangan itu. Pelepasan ketegangan sangat perlukan bagi kesehatan jasmani maupun rohani untuk dapat menghimpun tenaga dalam mencapai prestasi-prestasi kerja ataupun kehidupan yang lebih baik dalam masyarakat.

Jadi kesimpulannya bahwa Investasi Sektor Pariwisata merupakan investasi yang lakukan bidang pariwisata untuk mendukung pengembangan pariwisata terutama dalam memfasilitasi sarana parasana pariwisata dan juga destinasi pariwisata. Invetasi bidang pariwisata Indonesia sangat menjajikan hal ini karenakakan negara Indonesia merupakan salah satu tujuan wisata yang minati oleh tourism MancaNegara khususnya sector pariwisata Kota Batam dalam hal ini.

\section{Hasil Penelitian dan Pembahasaan}

\section{Investasi untuk memfasilitasi Sektor Pariwisata Kota Batam}

Dalam pembangunan ekonomi, sumber daya modal memegang peranan penting. dalam upaya meningkatkan pertumbuhan ekonomi suatu negara atau suatu daerah sangat ditentukan oleh meningkatnya akumulasi modal (investasi), terutama di sektor rill atau sektor produksi barang dan jasa. Investasi yang meningkat baik di sektor produksi bahan mentah maupun proses nilai tambah akan mendorong meningkatnya produksi nasional (GDP), mendorong kesempatan kerja yang lebih luas yang pada gilirannya meningkatkan kesejahteraan masyarakat. Akumulasi modal akan menentukan cepat atau lambatnya pertumbuhan ekonomi yang terjadi pada suatu negara atau wilayah. Dengan adanya akumulasi modal akan meningkatkan di laksanakannya spesialisasi sehingga produktivitas tenaga kerja meningkat yang berdampak terhadap bertambahnya investasi.

Gelobalisasi ekonomi telah mendorong kondisi perekonomian menjadi semakin kompleks dan kompetitif sehingga menuntut tingkat efisiensi usaha yang tinggi. Persaingan antar negara dan daerah sudah tidak dapat dihindari. Sementara output yang dihasilkan masingmasing negara atau daerah relatif sama. Dalam konteks ini negara atau daerah-daerah yang memiliki keunggulan komperatiflah yang akan memenangkan persaingan tersebut. Persaingan 
antar negara-negara yang mencoba untuk menarik investasi saat ini semakin ketat. Hal ini terjadi karena jumlah modal yang tersisa semakin terbatas dan keinginan untuk mendapatkan manfaat dari investasi tersebut semakin meningkat.

Faktor-faktor yang mempengaruhi iklim investasi di suatu negara atau daerah yang menentukan daya tarik bagi investor sangat banyak dan kompleks. Disamping perizinan yang lebih sederhana, singkat, mudah, dan pasti serta menciptakan stabilitas keamanan di wilayahnya sebagai faktor non-ekomomi dengan maksud agar investor merasa nyaman berinvestasi.

Di tingkat daerah, di samping keunggulan komperatif, sistem perizinan dan keamanan yang kondusif daya tarik investor untuk berinvestasi juga di tentukan oleh promosi-promosi yang dilakukan oleh pemerintah daerah. Bukti empiris menunjukkan bahwa investasi di bidang pariwisata telah memainkan peranan penting bagi peningkatan investasi di suatu daerah khussunya Kota Batam. Peran investasi yang di targetkan secara tepat sasaran mampu memainkan peran dalam pembangunan ekonomi dan pariwisata karena tidak hanya mempengaruhi daya tarik lokasi untuk investasi tetapi juga manfaat yang diperoleh bagi pertumbuhan ekonomi lokal, karena diseluruh potensi pariwisata di daerah khususnya Kota Batam harus sesuai dengan tepat sasaran dan berkelanjutan didalam negeri maupun diluar negeri melalui wadah kegiatan yang efektif dalam hal ini Dinas Pariwisata dan Kebudayaan Kota Batam khususnya.

Atas dasar pemikiran tersebut maka, investasi sector pariwisata Kota Batam penting untuk disusun. Hal ini juga diperkuat dengan adanya data gambar prosedur alur standar perizinan BPMPTSP Kota Batam, 2014 sebagai berikut:

\section{Gambar}

Prosedur Alur Standar perizinan Terpadu BPMPTSP Kota Batam 


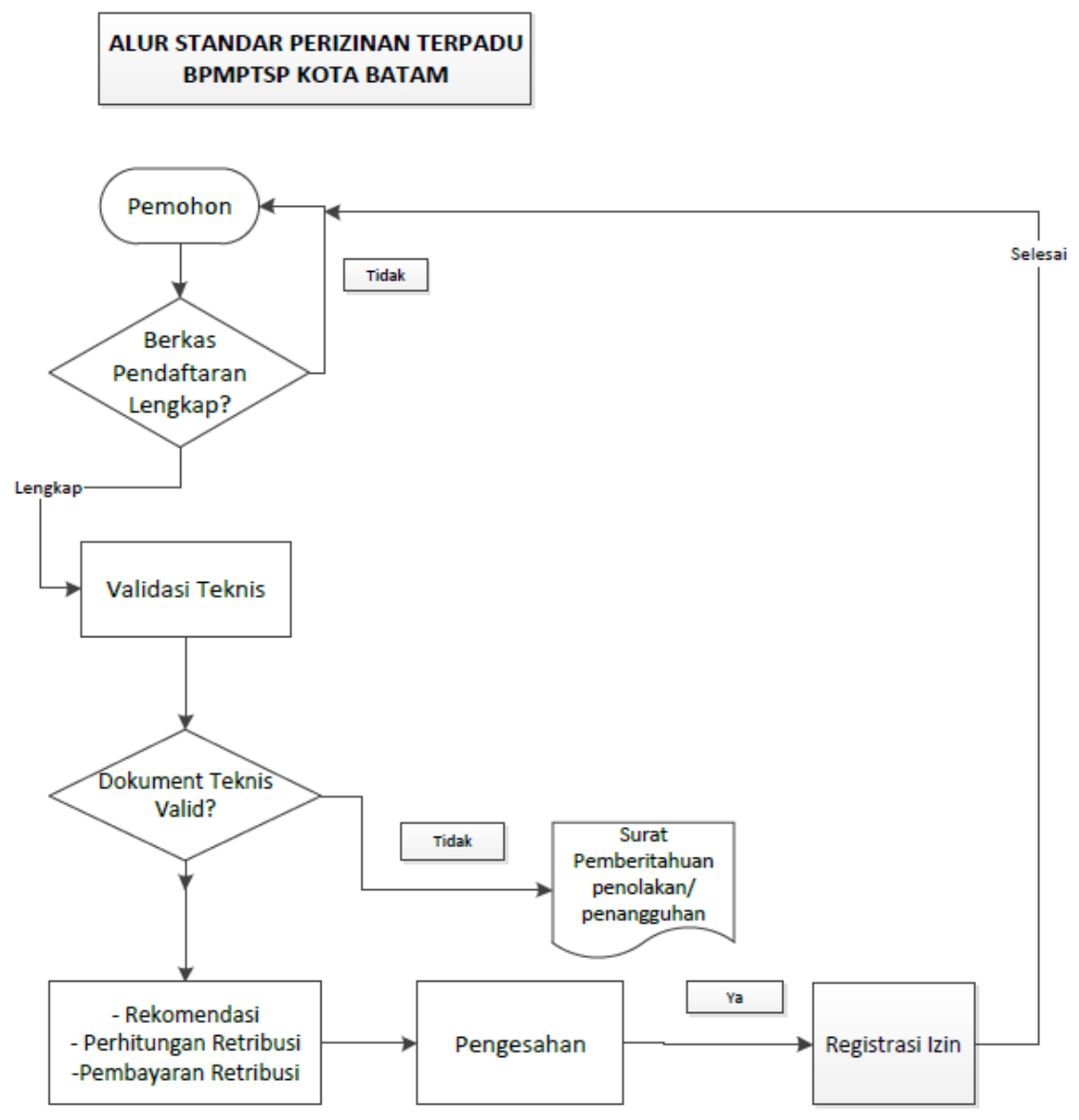

Sumber: BPMPTSP Kota Batam, 2014

Berdasarkan mekanisme prosedur alur standar perizinan BPMPTSP Kota Batam merupakan prosedur yang harus dilalui oleh para investor yang akan berinvestasi di Kota Batam. Mekanisme prosedur alur standar perizinan BPMPTSP Kota Bata ini sangat mudah diakses dan prosedural yang tidak berbelit-belit serta memperketat aturan-aturan untuk berinvestasi di Kota Batam, menjadikan banyak para investor yang menanamkan modalnya khususnya di bidang perhotelan, restoran, serta travel agent dilakukan baik investor asing maupun investor local di Kota Batam.

Kondisi Kota Batam yang nyaman dan keamanan dalam berinvestasi di Kota Batam, para investor tertarik untuk menanamkan modalnya dalam bidang usaha yang diliriknya. Dalam rangka mempermudah investor memperoleh perizinan dan non perizinan penanaman modal dalam melaksanakan kegiatan usaha memproduksi barang atau jasa melalui kepemilikan modal dalam negeri maupun modal asing. Pemerintah telah mengeluarkan ketentuan dan peraturan perundang-undangan mengenai pelayanan di bidang penanaman modal.

Landasan hukum penyelenggaraan pelayanan penanaman modal yang terkait dengan perizinan dan non perizinan sebagaimana tertuang dalam pasal 25 dan pasal 26 Undang-Undang nomor 25 tahun 2007 tentang penanaman modal. Pasal 25 ayat (4) menyebutkan bahwa setiap perusahaan penanaman modal yang akan melakukan kegiatan usaha wajib memiliki izin, dan ayat (5) menyatakan bahwa izin tersebut diperoleh melalui Sistem Pelayanan Terpadu Satu Pintu (PTSP). Hal ini lagi dipetegas lagi dalam pasal 26 ayat (1) menyebutkan bahwa PTSP bertujuan untuk membantu penanaman modal dalam memperoleh kemudahan pelayanan, fasilitas fiskal, dan informasi mengenai penanaman modal. Disamping itu lebih dipertegas lagi dalam peraturan peresiden Nomor 27 tahun 2009 tentang PTSP 
antara lain menyebutkan bahwa pelayanan perizinan dan non perizinan penanaman modal dapat dilakukan secara manual dan secara elektronik.

Sedangkan pedoman teknis pelayanan perizinan dan non perizinan penanaman modal serta prosedur pelaksanaannya diatur kembali dengan peraturan Kepala BKPM (PERKABKPM) yaitu pertama, Perka BKPM nomor 11 tahun 2009 tentang tata cara pelaksanaan, pembinaan dan Pelaporan Pelayanan Terpadu Satu Pintu di bidang Penanaman Modal. Kedua, Perka BKPM nomor 12 tahun 2009 tentang Pedoman Tata Cara Permohonan Penanaman Modal. Ketiga, Perka BKPM nomor 13 tahun 2009 tentang Pedoman Tata Cara Pengendalian Pelaksanaan Penanaman Modal. Keempat, Perka BKPM nomor 14 tahun 2009 tentang Sistem Pelayanan Informasi dan Perizinan Investasi secara Elektronik (SPIPISE). Kelima, SK Gubernur Kota Batam tentang pelimpahan sebagian kewenangan Gubernur kepada kepala BPM untuk pemberian perizinan dan non perizinan penanaman modal.

Standar Pelayanan Pendaftaran Penanaman Modal Kota Batam mengacu kepada dasar hukum (BPMPTSP Kota Batam, 2014) yaitu:

1. UU No. 32 Tahun 2004 tentang Pemerintahan Daerah

2. UU No. 25 Tahun 2007 tentang Penanaman Modal

3. PP No. 38 Tahun 2007 tentang Pembagian Urusan Pemerintahan Antara Pemerintah, Pemerintah Daerah Provinsi, dan Pemerintah Daerah Kabupaten/Kota

4. Perpres No. 27 Tahun 2009 tentang Pelayanan Terpadu Satu Pintu di Bidang Penanaman Modal

5. Perpres No. 36 Tahun 2010 tentang Daftar Bidang Usaha yang Tertutup dan Bidang Usaha yang Terbuka dengan Persyaratan di Bidang Penanaman Modal

6. Perka BKPM No. 12 Tahun 2009 tentang Pedoman dan Tata Cara Permohonan Penanaman Modal

7. Perda Kota Batam No. 11 Tahun 2007 tentang Pembentukan Susunan Organisasi Dan Tata Kerja Lembaga Teknis Daerah Kota Batam

8. Perda Kota Batam No. 1 Tahun 2010 tentang Urusan Pemerintahan Yang Menjadi Kewenangan Pemerintahan Daerah

9. Perwako No. 09 Tahun 2011 tentang Pedoman Tata Cara Permohonan Penanaman Modal di Kota Batam

10. Perwako No. 71 Tahun 2012 tentang Penyelenggaraan Pelayanan Terpadu Satu Pintu

Adapun Persyaratan Pelayanan Penanaman Modal Kota Batam (BPMPTSP Kota Batam, 2014) yaitu:

1. Fotokopi Akta Pendirian Perusahaan dan Perubahannya, beserta pengesahan dari Kementerian Hukum dan HAM untuk pemohon adalah badan usaha Indonesia

2. Fotokopi KTP pemohon/direksi perusahaan

3. Fotokopi NPWP Perusahaan

4. Surat Kuasa bermaterai cukup untuk pengurusan permohonan yang tidak dilakukan secara langsung oleh pemohon/direksi perusahaan

5. Fotokopi KTP penerima kuasa

6. Surat Keterangan Domisili Usaha

Adapun ketersediaan dalam memfasilitasi prasarana pariwisata yang ada di obyek wisata Kota Batam, merupakan prasarana penunjang fasilitas yang tepat dikelola oleh Dinas Pariwisata dan Kebudayaan Kota Batam guna untuk meningkatkan fasilitas obyek wisata sekitar, hal ini diperkuat dengan data fasilitas prasaran obyek wisata sebagai tabel beikut:

\section{Tabel}

\section{Data nama obyek wisata dan prasarana obyek wisata Kota Batam}




\begin{tabular}{|c|c|}
\hline Nama Obyek Wisata & Prasaranan Obyek Wisata \\
\hline Wisata Budaya & $\begin{array}{l}\text { Pintu Gerbang, Penataan, Parkiran, Transportasi, } \\
\text { Gazebo, Taman Rekreasi, Toilet Umum, Jaringan } \\
\text { Listrik, Warung, Jalan Setapak, jalan Linkungan, Bak } \\
\text { Sampah, Hotel. }\end{array}$ \\
\hline Wisata Bahari/Laut & $\begin{array}{l}\text { Pintu Gerbang, Penataan, Parkiran, Transportasi, } \\
\text { Gazebo, Toilet Umum, Jaringan Listrik, Warung, } \\
\text { Jalan Setapak, jalan Linkungan, Bak Sampah, Wisata } \\
\text { Bahari, Sunset, Parkiran, Transportasi, Taman } \\
\text { Rekreasi dan Olahraga, Kuliner. }\end{array}$ \\
\hline Wisata Belanja & $\begin{array}{l}\text { Pintu Gerbang, Penataan, Parkiran, Transportasi, } \\
\text { Toilet Umum, Jaringan Listrik, Bak Sampah, Hotel, } \\
\text { Wisata Belanja, Musholla, ATM Center, Restaurant. }\end{array}$ \\
\hline Wisata Olah Raga & $\begin{array}{l}\text { Pintu Gerbang, Penataan, Parkiran, Transportasi, } \\
\text { Gazebo, Toilet Umum, Jaringan Listrik, Jalan } \\
\text { Setapak, Bak Sampah, Arena Bermain dan Olahraga, } \\
\text { Kuliner. }\end{array}$ \\
\hline Wisata Religi & $\begin{array}{l}\text { Parkiran, Transportasi, Toilet Umum, Musholla, } \\
\text { Kuliner, Bak Sampah, Jaringan Listrik, Wisata } \\
\text { Sejarah/Religi }\end{array}$ \\
\hline Wisata Sejarah & $\begin{array}{l}\text { Pintu Gerbang, Penataan, Parkiran, Transportasi, } \\
\text { Gazebo, Toilet Umum, Jaringan Listrik, Warung, } \\
\text { Jalan Setapak, jalan Linkungan, Bak Sampah, } \\
\text { Musholla, Wisata Sejarah/Religi }\end{array}$ \\
\hline $\begin{array}{l}\text { Wisata Perkebunan } \\
\text { (Ekowisata) }\end{array}$ & $\begin{array}{l}\text { Pasar Seni, Pusat Accesoris, Sovenir, Toilet, } \\
\text { Penataan, Parkiran, Transportasi, Warung, Jalan Bak } \\
\text { Sampah. }\end{array}$ \\
\hline Wisata MICE & $\begin{array}{l}\text { Pintu Gerbang, Penataan, Parkiran, Transportasi, } \\
\text { Gazebo, Toilet Umum, Jaringan Listrik, Warung, } \\
\text { Jalan Setapak, jalan Linkungan, Bak Sampah., Hotel, } \\
\text { Kuliner Taman Rekreasi. }\end{array}$ \\
\hline
\end{tabular}

Sumber: Dinas Pariwisata dan Kebudayaan Kota Batam, 2014

Usaha dan cara yang dilakukan oleh Dinas Pariwisata dan Kebudayaan Kota Batam untuk melengkapi sarana dan prasaranan penunjang pariwisata adalah dengan pembangunan sarana dan prasarana yang belum ada di obyek wisata dan menjaga serta memelihara sarana dan prasarana yang telah ada di obyek wisata begitu juga memperbaiki ssarana dan prasarana yang sudah rusak, tak layak, sehingga dapat di manfaatkan kembali.

Adapun dasar hukum standar pelayanan tanda daftar usaha pariwisata Kota Batam (BPMPTSP Kota Batam, 2014) meliputi:

1. UU No. 32 Tahun 2004 tentang Pemerintahan Daerah

2. Undang-Undang No. 10 Tahun 2009 tentang Kepariwisataan

3. PP No. 38 Tahun 2007 tentang Pembagian Urusan Pemerintahan Antara Pemerintah, Pemerintah Daerah Provinsi, dan Pemerintah Daerah Kabupaten/Kota

4. Permenbudpar No. 85 Tahun 2010 tentang Tata Cara Pendaftaran Usaha Jasa Perjalanan Pariwisata

5. Permenbudpar No. 86 Tahun 2010 tentang Tata Cara Pendaftaran Usaha Penyediaan Akomodasi 
6. Permenbudpar No. 87 Tahun 2010 tentang Tata Cara Pendaftaran Usaha Jasa Makanan dan Minuman

7. Permenbudpar No. 88 Tahun 2010 tentang Tata Cara Pendaftaran Usaha Kawasan Pariwisata

8. Permenbudpar No. 89 Tahun 2010 tentang Tata Cara Pendaftaran Usaha Jasa Transportasi Wisata

9. Permenbudpar No. 90 Tahun 2010 tentang Tata Cara Pendaftaran Usaha Daya Tarik Wisata

10. Permenbudpar No. 91 Tahun 2010 tentang Tata Cara Pendaftaran Usaha Penyelenggaraan Kegiatan Hiburan dan Rekreasi

11. Permenbudpar No. 92 Tahun 2010 tentang Tata Cara Pendaftaran Usaha Jasa Pramuwisata

12. Permenbudpar No. 93 Tahun 2010 tentang Tata Cara Pendaftaran Usaha Jasa Penyelenggaraan Pertemuan, Perjalanan Insentif, Konferensi dan Pameran

13. Permenbudpar No. 94 Tahun 2010 tentang Tata Cara Pendaftaran Usaha Jasa Konsultan Pariwisata

14. Permenbudpar No. 95 Tahun 2010 tentang Tata Cara Pendaftaran Usaha Jasa Informasi Pariwisata

15. Perda Kota Batam No. 11 Tahun 2007 tentang Pembentukan Susunan Organisasi Dan Tata Kerja Lembaga Teknis Daerah Kota Batam

16. Perda Kota Batam No. 1 Tahun 2010 tentang Urusan Pemerintahan Yang Menjadi Kewenangan Pemerintahan Daerah

17. Perwako No. 71 Tahun 2012 tentang Penyelenggaraan Pelayanan Terpadu Satu Pintu

Untuk persyaratan pelayanannya tanda daftar usaha pariwisata Kota Batam (BPMPTSP Kota Batam, 2014) meliputi:

1. Surat Permohonan Pendaftaran Usaha Pariwisata

2. Fotokopi Akta Pendirian Badan Usaha dan Akta Perubahan (jika ada) beserta pengesahannya atau Fotokopi KTP untuk usaha perseorangan

3. KTP Direktur

4. NPWP Perusahaan

5. Fotokopi Izin Teknis:

6. Izin Mendirikan Bangunan (IMB) bagi usaha yang memerlukan bangunan fisik

7. Izin Gangguan (HO)

8. Fotokopi Dokumen Lingkungan:

a. Dokumen AMDAL untuk:

- Usaha Kawasan Pariwisata untuk semua luasan

- Usaha Taman Rekreasi yang luasnya lebih dari 100 ha

- Usaha Lapangan Golf untuk semua luasan

b. Dokumen UKL-UPL atau SPPL untuk usaha pariwisata di luar usaha kawasan pariwisata, usaha taman rekreasi dan usaha lapangan golf

9. Surat Pernyataan tertulis bermaterai Rp. 6000 dari pengusaha yang menjamin bahwa data dan dokumen yang diserahkan absah dan benar

10. Surat Keterangan Domisili Usaha 
11. Pas foto Direktur berwarna $3 \times 4$ (3 lbr)

12. Surat Kuasa di atas materai Rp. 6000 jika menguasakan pengurusan izin kepada pihak lain

\section{Investasi untuk pengembangan Sektor Pariwisata Kota Batam}

Investasi diarahkan sesuai dengan pembangunan yang dilakukan pemerintah pada umumnya dan bidang sector pariwisata khususnya. Pengembangan investasi ini ditunjukan untuk melengkapi dan meningkatkan sarana dan prasarana sesuai perkembangan dan permintaan pasar, agar keberadaan sektor pariwisata mampu menciptakan kesejahtraan rakyat dan meningkatkan pendapatan asli daerah (PAD). Selain itu juga adapun program prioritas pengembangan potensi pariwisata yang ditawarkan seperti pengembangan sarana dan prasarana pariwisata, hotel dan restoran bertaraf internasional yaitu kerjasama dibidang kepariwisataan salah satunya untuk memperkenalkan obyek wisata yang ada di Kota Batam.

Adanya pengembangan untuk memfasilitasi sarana dan prasarana sektor pariwisata di Kota Batam, upaya untuk meningkatkan investor pada sector pariwisata khususnya. Investasi yang banyak dilirik oleh investor atau penanam modal dengan melihat perkembangan pariwisata Kota Batam yang semakin berkembang, para investor melirik sektor pariwisata dalam bentuk investasi yang ditanamkan di Kota Batam. Adapun bentuk perkembangan dan rekafitulasi kesepakatan bersama (MoU) yang telah dilakukan oleh pemerintah Kota batam dengan pemerintah provinsi/kabupaten/kota dalam dan luar negeri selama tahun anggaran 2007-2014 sebagai wujud dalam pengembangan investasi sector pariwisata di Kota Batam.

Hal ini diperkuat dengan adanya data perkembangan dan rekafitulasi kesepakatan bersama (MoU) yang telah dilakukan oleh pemerintah Kota batam dengan pemerintah Provinsi/Kabupaten/Kota dalam dan luar negeri selama tahun anggaran 2007-2014 seperti uraian table berikut:

Tabel

Data perkembangan dan rekafitulasi kesepakatan bersama (MoU) Kota Batam, 20072014

\begin{tabular}{|c|c|c|c|c|c|}
\hline No & $\begin{array}{l}\text { Nama Pemerintahan } \\
\text { Daerah }\end{array}$ & Penandatanganan & $\begin{array}{l}\text { Jangka } \\
\text { Waktu }\end{array}$ & Berakhir & keterangan \\
\hline 1 & Pemko Surabaya & $\begin{array}{l}\text { Surabaya, } 23 \text { Juli } \\
2007\end{array}$ & 5 Tahun & 23 Juli 2013 & - \\
\hline 2 & Pemko Semarang & $\begin{array}{l}\text { Semarang, } 10 \text { Agus } \\
2007\end{array}$ & 5 Tahun & $\begin{array}{l}10 \text { Agust } \\
2012\end{array}$ & - \\
\hline 3 & Pemko Bandung & Batam, 23 Juli 2007 & 5 Tahun & 11 Des 2012 & - \\
\hline 4 & Provinsi NTB & NTB, 26 Maret 2008 & 3 Tahun & $\begin{array}{l}26 \text { Maret } \\
2013\end{array}$ & - \\
\hline 5 & PemKab kulon Progo & Batam, 22 April 2008 & 5 Tahun & $\begin{array}{l}22 \text { April } \\
2013\end{array}$ & - \\
\hline 6 & Pemko Banjarmasin & Batam, 6 Mei 2009 & 3 Tahun & 6 Mei 2012 & - \\
\hline 7 & Pemko Banjarmasin & Batam, 2 Mei 2013 & 5 Tahun & 2 Mei 2016 & $\begin{array}{c}\text { Di t.tangani Wakil Walikota } \\
\text { kedua daerah }\end{array}$ \\
\hline 8 & Pemko Bogor & Batam, 27 Juli 2009 & 3 Tahun & 27 Juli 2012 & No.100/09/NK/HUK/2009 \\
\hline
\end{tabular}




\begin{tabular}{|l|l|l|l|l|l|}
\hline & & & & No.05/MoU/HK/VII/2009 \\
\hline 9 & Pemko Surakarta & Batam, 12 Juni 2010 & 3 Tahun & $\begin{array}{l}\text { 12 Juni } \\
2013\end{array}$ & $\begin{array}{l}\text { No.01/MoU/HK/VI/2010 } \\
\text { No.193/2.070 }\end{array}$ \\
\hline 10 & Pemko Medan & Batam, 17 April 2014 & 1 Tahun & $\begin{array}{l}17 \text { April } \\
2015\end{array}$ & $\begin{array}{l}\text { No. 193/5564 } \\
\text { No.01/MoU/HK/IV/2014 }\end{array}$ \\
\hline 11 & Pemko Surabaya & $\begin{array}{l}\text { Surabaya, 31 Mei } \\
2014\end{array}$ & 1 Tahun & 31 Mei 2015 & $\begin{array}{l}\text { No.415.4/2704/436.2.3/2014 } \\
\text { No.06/MoU/HK/V/2014 }\end{array}$ \\
\hline
\end{tabular}

Sumber: BPM-PTSP Kota Batam, 2014

\section{Investasi untuk penguatan modal pelaku Pariwisata Kota Batam}

Dalam penguatan modal pelaku pariwista Kota Batam berupaya untuk meningkatkan dan mengembangkan serta menjalin kerjasama dengan para pelaku pariwisata. Dinas Pariwisata dan Kebudayaan Kota Batam melakukan kerjasama serta memberikan penguatan modal kepada para pelaku pariwisata, upaya untuk bisa menarik investor di Kota Batam. Seiring dengan perkembangan teknologi yang semakin moderen dalam mengakses informasi untuk para wisatawan mancanegara maupun wisatwan local maupun calon investor guna mendapatkan informasi seputar obyek wisata yang dijadikan tujuan wisata. Adapun penguatan modal tersebut berupa pemberian pelatihan standarisasi manajemen pelayanan Guide, hotel, dan restoran serta memberikan penyuluhan terhadap kelompok sadar wisata dan sapta pesona yaitu para pelaku wisata.

Untuk memperkuat argumentasi diatas, Dinas pariwisata dan Kebudayaan Kota Batam mengembangkan sosialisai dan penerapan serta pengawasan standarisasi kepada para pelaku usaha pariwisata seperti tabel dibawah ini:

\section{Tabel}

Data program kegiatan pengauatan modal usaha pariwisata Dinas Kebudayaan dan Pariwisata Kota Batam, 2014

\begin{tabular}{|c|l|l|}
\hline No & \multicolumn{1}{|c|}{ Sasaran } & \multicolumn{1}{|c|}{ Indikator Sasaran } \\
\hline $\mathbf{1}$ & $\begin{array}{l}\text { pelatihan standarisasi manajemen } \\
\text { pelayanan Guide, Hotel, dan } \\
\text { Restoran, pramuwisata }\end{array}$ & $\begin{array}{l}\text { terlaksananya pelatihan standarisasi } \\
\text { manajemen pelayanan Guide, Hotel dan } \\
\text { Restoran, peramuwisata }\end{array}$ \\
\hline $\mathbf{2}$ & $\begin{array}{l}\text { penyuluhan terhadap kelompok } \\
\text { sadar wisata dan sapta pesona }\end{array}$ & $\begin{array}{l}\text { terlaksananya penyuluhan terhadap } \\
\text { kelompok sadar wisata }\end{array}$ \\
\hline $\mathbf{3}$ & $\begin{array}{l}\text { pengiriman kelompok sadar wisata } \\
\text { dan sapta pesona ke luar daerah }\end{array}$ & $\begin{array}{l}\text { terlaksananya pengiriman kelompok } \\
\text { sadar wisata ke luar daerah }\end{array}$ \\
\hline $\mathbf{4}$ & $\begin{array}{l}\text { pelaksanaan koordinasi } \\
\text { pembangunan kemitraan pariwisata }\end{array}$ & $\begin{array}{l}\text { terlaksananya koordinasi kemitraa antar } \\
\text { pelaku pariwisata Kota Batam } \\
\text { (7 klp.usaha pariwisata) }\end{array}$ \\
\hline $\mathbf{5}$ & $\begin{array}{l}\text { pemantauan dan evaluasi } \\
\text { pelaksanaan program peningkatan } \\
\text { kemitraan }\end{array}$ & $\begin{array}{l}\text { terlaksananya peningkatan pengawasan } \\
\text { dan pemantauan usaha pariwisata }\end{array}$ \\
\hline
\end{tabular}

Sumber: Dinas Pariwisata dan Kebudayaan Kota Batam, 2014

Berdasarkan tabel diatas merupakan bentuk penguatan modal terhadap para pelaku usaha pariwisata, Penguatan modal yang diberikan kepada pelaku usaha wisata sangat penting dalam penunjang kepariwisataan Kota Batam. Terciptanya penguatan modal ini akan mempermudah Dinas Pariwisata dan Kebudayaan Kota Batam dalam menarik investor khususnya pada sector pariwisata. Terjalinnya kerjasama dengan pelaku usaha wisata ini 
diharapkan mampu menarik minat kunjung wisatawan mancanegara maupun wisatawan lokal serta investor di Kota Batam. Hal ini memiliki Peran penting dalam moda wisata juga dikendalikan oleh para usaha wisata yang memiliki kesadaran akan pentingnya pariwisata daerah dalam mensejahtrakan masyarakat sekitar.

Hal ini diperjelas juga dengan data dalam investasi penguatan modal pariwisata Kota Batam. Adapun Bentuk Perizinan Bidang Pariwisata Kota Batam dalam penguatan investasi sector pariwisata meliputi hal Dasar Hukum yang mengikat para investor dalam melakukan investasi usaha wisata, hal ini antara lain:

1. Undang-Undang No. 10 Tahun 2009 tentang Kepariwisataan;

2. Perda No.17 Tahun 2001 tentang Kepariwisataan di Kota Batam

3. Permenbudpar No. 85 Tahun 2010 tentang Tata Cara Pendaftaran Usaha Jasa Perjalanan Pariwisata

4. Permenbudpar No. 86 Tahun 2010 tentang Tata Cara Pendaftaran Usaha Penyediaan Akomodasi

5. Permenbudpar No. 87 Tahun 2010 tentang Tata Cara Pendaftaran Usaha Jasa Makanan dan Minuman

6. Permenbudpar No. 88 Tahun 2010 tentang Tata Cara Pendaftaran Usaha Kawasan Pariwisata

7. Permenbudpar No. 89 Tahun 2010 tentang Tata Cara Pendaftaran Usaha Jasa Transportasi Wisata

8. Permenbudpar No. 90 Tahun 2010 tentang Tata Cara Pendaftaran Usaha Daya Tarik Wisata

9. Permenbudpar No. 91 Tahun 2010 tentang Tata Cara Pendaftaran Usaha Penyelenggaraan Kegiatan Hiburan dan Rekreasi

10. Permenbudpar No. 92 Tahun 2010 tentang Tata Cara Pendaftaran Usaha Jasa Pramuwisata

11. Permenbudpar No. 93 Tahun 2010 tentang Tata Cara Pendaftaran Usaha Jasa Penyelenggaraan Pertemuan, Perjalanan Insentif, Konferensi dan Pameran

12. Permenbudpar No. 94 Tahun 2010 tentang Tata Cara Pendaftaran Usaha Jasa Konsultan Pariwisata

13. Permenbudpar No. 95 Tahun 2010 tentang Tata Cara Pendaftaran Usaha Jasa Informasi Pariwisata

Selain dasar hukum diatas, masih terdapatnya Tanda Daftar Usaha Pariwisata (TDUP) untuk penguatan modal investasi pariwisata Kota Batam yang terdiri dari: Usaha Jasa Perjalanan Wisata,Usaha Penyediaan Akomodasi,Usaha Jasa Makanan dan Minuman,Usaha Kawasan Pariwisata,Usaha Jasa Transportasi Pariwisata,Usaha Daya Tarik Wisata,Usaha Penyelenggaraan Kegiatan Hiburan dan Rekreasi,Usaha Jasa Pramuwisata,Usaha Jasa Penyelenggaraan Pertemuan, Perjalanan Insentif, Konferensi dan Pameran,Usaha Jasa Konsultan Pariwisata,Usaha Jasa Informasi Pariwisata,Usaha Wisata Tirta, dan Usaha SPA.

Adapun Persyaratan yang harus terpenuhi oleh para pemohon yang akan melakukan investasi usaha pariwisata yang ada di Kota Batam meliputi:

1. Surat Permohonan Pendaftaran Usaha Pariwisata

2. Surat Keapsahan/Pernyataan

3. KTP Direktur

4. NPWP Perusahaan

5. Surat Pernyataan Kesanggupan Pengelolaan dan Pemantauan Lingkungan Hidup (sppl)

6. Fotokopi Izin Teknis; 
- Izin Mendirikan Bangunan (IMB) bagi usaha yang memerlukan bangunan fisik

- Izin Gangguan (HO)

7. Fotokopi Dokumen Lingkungan:

8. Dokumen AMDAL untuk:

- Usaha Kawasan Pariwisata untuk semua luasan

- Usaha Taman Rekreasi yang luasnya lebih dari 100 ha

- Usaha Lapangan Golf untuk semua luasan

9. Dokumen UKL-UPL atau SPPL untuk usaha pariwisata di luar usaha kawasan pariwisata, usaha taman rekreasi dan usaha lapangan golf

10. Surat Pernyataan tertulis bermaterai Rp. 6000 dari pengusaha yang menjamin bahwa data dan dokumen yang diserahkan absah dan benar

11. Surat Keterangan Domisili Usaha

12. foto lokasi usaha

13. Denah lokasi

14. Pas foto Direktur berwarna $3 \times 4$ (3 lbr)

15. Surat Kuasa di atas materai Rp. 6000 jika menguasakan pengurusan izin kepada pihak lain, dan Fotokopi KTP yang dikuasakan

Semua persyaratan diatas, merupakan kewajiban yang harus diketahui dan di penuhi oleh para investor yang akan melakukan investasi usaha pariwisata yang diminati oleh para pelaku usaha pariwisata dalam rangka salah satunya untuk penguatan modal usaha pariwisata tersebut. Dengan adanya daya tarik destinasi obyek wisata yang dimiliki oleh sector pariwisata Kota Batam, hal ini menjadi daya pikat tersendiri bagi para investor untuk bisa menanamkan modal mereka sekaligus menjalin kerjasama dalam sector kepariwisataan tersebut. Hal ini juga para pelaku pariwisata memiliki andil yang cukup besar terhadap investasi kepariwisataan yang dimiliki daerah. Dalam hal ini adalah pariwisata Kota Batam. pelaku usaha juga dapat sekaligus memberikan fasilitas penunjang bagi para wisatawan khususnya mancanegara dalam berinvestasi seperti usaha jasa perhotelan, restoran dan travel.

\section{Kesimpulan}

Berdasarkan uraian dan pertanyaan penelitian yang ada, maka untuk memperoleh gambaran yang utuh dan menyeluruh dapat ditarik beberapa kesimpulan sebagai berikut:

1. Investasi dalam memfasilitasi permohonan perizinan penanaman modal di Kota Batam diberikan dengan geratis serta pelayanannya tidak berbelit-belit yang memudahkan para investor menanamkan modalnya disektor pariwisata,

2. investasi dalam mengembangkan obyek pariwisata yaitu meningkatkan pengembangan obyek wisata Kota Batam seperti pengembangan destinasi pariwisata yang meliputi: peningkatan pembangunan sarana dan prasarana pariwisata, pengembangan jenis dan paket wisata unggulan, pengembangan sosialisasi dan penerapan serta pengawasan standarisasi. Pengembangan kemitraan meliputi: pengembangan dan penguatan informasi dan database, pelaksanaan koordinasi pembangunan kemitraan pariwisata, pemantauan dan evaluasi pelaksanaan program peningkatan kemitraan. Adapun wujud peningkatan pengembangan obyek wisata di Kota Batam dalam meningkatkan pembangunan sarana dan prasarana obyek wisata.

3. investasi untuk penguatan modal pelaku pariwisata Kota Batam berupa pelatihan standarisasi manajemen pelayanan guide/hotel/restoran dan pramuwisata, Penyuluhan terhadap kelompok sadar wisata dan sapta pesona, pengiriman kelompok sadar wisata dan sapta pesona keluar daerah, melakukan koordinasi pembangunan kemitraan pariwisata, dan pemantauan dan evaluasi pelaksanaan program peningkatan kemitraan.

\section{Saran}

Berdasarkan hasil temuan yang dituangkan dalam kesimpulan, juga perlu dikemukakan saransaran sebagai berikut: 
1. Diharapkan Pemerintah Kota Batam mendorong pertumbuhan investasi sektor pariwisata, serta semakin meningkatkan pergerakkan investasi sektor pariwisata.

2. Pemerintah Kota Batam diharapkan lebih fokus memperhatikan perkembangan pembangunan sektor pariwisata yang dapat menyerap tenaga kerja lebih banyak lagi pada sektor pariwisata.

\section{DAFTAR PUSTAKA}

Anastasia Diana dan Fandy Tjiptono, Prinsip Dinamika Pemasaran, J dan J Learning Yogyakarta, 2000.

Alma Buchari, Manajemen Pemasaran dan Pemasaran Jasa, Penerbit ALFABETA, Bandung 2011.

Armstrong Kotler, Dasar-Dasar Pemasaran, Penerbit CV Intemedia: Jakarta, 1998.

Chadid Narbuko dan Abu Achmadi, Metodologi Penelitian, Bumi Aksara. Jakarta, 2007.

David W. Cravens, Pemasaran Strategis, Penerbit Erlangga, 1996.

Doli D. Siregar, Manajemen Aset, PT Gramedia Pustaka Utama: Jakarta, 2004.

M. J. Prajogo, Pengatar Pariwisata Indonesia, Penerbit Direktorat Jenderal Pariwisata Departemen Perhubungan, 1976.

Freddy Rankuti, Manajemen Pemasaran. Penerbit PT Gramedia Pustaka Utama: Jakarta, 2004.

Gamal Suwantoro, Dasar-dasar Pariwisata, Penerbit PT. Andi yogyakarta, 1997.

Herwan Kartajaya, Marketing Plus 2000 Siasat Memenangkan Persaingan Global, PT Gramedia Pustaka Utama Mark Plus Profesional Service Harian Bisnis Indonesia Jakarta, 2001.

Happy, Marpaung, Pengetahuan Kepariwisataan, ALFABETA: Bandung, 2000

I Ketut Suwena dan I Gst Ngr Widyatama, Pengetahuan Dasar Ilmu Pariwisata, Udayana University Press, 2010.

J David Hunger dan Thomas L. Wheeen, Manajemen Strategis, Andi Yogyakarta, 2003.

Kuntjoro Suwandi, Panduan Cerdas Investasi,Reksa Dana,Saham,Stock Option,Valas,Emas, Penerbit Pinang Merah Publisher, Yogyakarta, 2011.

Kotler Philip, Dasar-Dasar Pemasaran, Penerbit PT. Midas Surya Grafindo, Jakarta, 1987.

Lexy J. Moleong, Metode Penelitian Kualitatif, PT Remaja Rosdakarya, Bandung, 2011.

Pitana I Gde dan I Ketut Surya Diarta, Pengatar Ilmu Pariwisat, Penerbit Andi, Jakarta, 2009.

Sugiono, Metode Penelitian Pendidikan (PendekatanKuantitatif, Kualitatif, dan R\&D), Bandung: Alfabeta, 2010.

Suharno dan Yudi Sutarso, Marketing In Practice. Penerbit Graha Ilmu, 2010.

Sofyan Efendi dan Masri Singarimbun, Metode Penelitian Survey, LP3ES. Jakarta, 1984.

Sofyan Assauri, Manajemen Pemasaran, Dasar Konsep dan Strategi, Penerbit PT. Damar Mulia Pustaka, Jakarta, 1999.

Tjiptono Fandy, Strategi Pemasaran, Edisi III, CV. ANDI OFFSET, ANDI Yogyakarta, 2008.

Tandelilin Eduardus, Portofolio dan Investasi Teori dan Aplikasi, Penerbit KANISIUS (Anggota IKAPI), Yogyakarta, 2010.

W.J.S. Poerwadarminta, Kamus Umum Bahasa Indonesia, Penerbit Balai Pustaka, Jakarta, 1976.

Yoeti Oka A, Pengantar Ilmu Pariwisata, penerbit PT. Angkasa, Bandung, 1996.

Yoeti A, Oka, Perencanaan Strategis Pemasaaran Daerah Tujuan Wisata, Jakarta: Pradnya Paramita, 2005

Sumber lain

Laporan Akuntabilitas Kinerja Instansi Pemerintah (Lakip) Dinas Pariwisata dan Kebudayaan Kota Batam, Tahun 2014

Rencana Kerja (RENJA), Satuan Kerja Perangkat Daerah (SKPD), Dinas Pariwisata dan Kebudayaan Kota Batam, Tahun 2014

Proyek Investasi Kota Batam, Badan Koordinasi Modal dan Perizinan Terpadu Tahun 2012.

Data Usaha Pariwisata (Direktori), Pariwisata dan Kebudayaan Kota Batam, Tahun 2014.

Dinas Kebudayaan dan Pariwisata Kota Batam, (http://skpd.batamkota.go.id/pariwisata), Tahun 2013.

BPM-PTSP Kota Batam, (http://skpd.batamkota.go.id/penanamanmodal), Tahun 2014 